Article type : Narrative review

Article begins on page three of this document.

\begin{tabular}{|l|l|l|}
\hline Title & Understanding the diagnosis of prostate cancer
\end{tabular}

\title{
Authors:
}

\begin{tabular}{|c|c|c|c|c|c|c|c|c|c|c|c|}
\hline & Title & $\begin{array}{l}\text { First } \\
\text { name }\end{array}$ & $\begin{array}{l}\text { Mid } \\
\text { inits }\end{array}$ & Last name & $\begin{array}{l}\text { Postnom } \\
\text { (eg, PhD) }\end{array}$ & Position1 & Address1 & Position2 & Address2 & Tel & Email \\
\hline 1 & Dr. & Xuan Rui & $\mathrm{S}$ & Ong & & $\begin{array}{l}\text { Urology } \\
\text { research } \\
\text { fellow }\end{array}$ & 1 & & 2 & & $\begin{array}{l}\text { ongxrs@gm } \\
\text { ail.com }\end{array}$ \\
\hline 2 & Dr. & Dominic & & Bagguley & & & 1 & & 2 & & $\begin{array}{l}\text { dominic.bag } \\
\text { guley@gmail } \\
\text {.com }\end{array}$ \\
\hline 3 & $\begin{array}{l}\text { Asso } \\
\text { C. } \\
\text { Prof. }\end{array}$ & John & W & Yaxley & FRACS & & 3 & & 4 & & $\begin{array}{l}\text { john@wesle } \\
\text { yurologyclini } \\
\text { c.com.au }\end{array}$ \\
\hline 4 & $\begin{array}{l}\text { Asso } \\
\text { c. } \\
\text { Prof. }\end{array}$ & Arun & $A$ & Azad & $\begin{array}{l}\text { MBBS, PhD, } \\
\text { FRACP }\end{array}$ & & 5 & & 2 & & $\begin{array}{l}\text { arun.azad@ } \\
\text { petermac.or } \\
\text { g }\end{array}$ \\
\hline 5 & Prof. & Declan & G & Murphy & FRCS Urol & $\begin{array}{l}\text { Director of } \\
\text { GU } \\
\text { Oncology }\end{array}$ & 5 & & 2 & & $\begin{array}{l}\text { declan.murp } \\
\text { hy@peterma } \\
\text { c.org }\end{array}$ \\
\hline 6 & $\begin{array}{l}\mathrm{A} / \mathrm{Pr} \\
\text { of }\end{array}$ & Nathan & & $\begin{array}{l}\text { Lawrentsc } \\
\text { huk }\end{array}$ & $\begin{array}{l}\text { PhD, MBBS, } \\
\text { FRACS }\end{array}$ & $\begin{array}{l}\text { Director of } \\
\text { Urology, } \\
\text { Royal } \\
\text { Melbourn } \\
\text { e Hospital }\end{array}$ & 1 & & 2 & 5 & $\begin{array}{l}\text { lawrentschuk } \\
@ g m a i l . c o m\end{array}$ \\
\hline
\end{tabular}

\begin{tabular}{|l|l|}
\hline Number of corresponding author: & 6 \\
\hline $\begin{array}{l}\text { Number of alternative corresponding } \\
\text { author: }\end{array}$ & \\
\hline
\end{tabular}

Addresses:

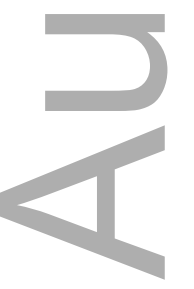

This is the author manuscript accepted for publication and has undergone full peer review but has not been through the copyediting, typesetting, pagination and proofreading process, which may lead to differences between this version and the Version of Record. Please cite this article as doi: 10.1002/MJA2.50820

This article is protected by copyright. All rights reserved 


\begin{tabular}{|c|c|c|c|c|c|c|}
\hline & Institution & Postal address & City & State & $\begin{array}{l}\text { Post } \\
\text { Code }\end{array}$ & Nation \\
\hline 1 & $\begin{array}{l}\text { EJ Whitten Prostate Cancer Research } \\
\text { Centre at Epworth Healthcare }\end{array}$ & Grey St, East Melbourne & Melbourne & VIC & 3005 & \\
\hline 2 & $\begin{array}{l}\text { University of Melbourne, Department of Surgery } \\
\text { and Department of Urology, Royal Melbourne } \\
\text { Hospital }\end{array}$ & Grattan street & Melbourne & VIC & 3010 & \\
\hline 3 & University of Queensland & St Lucia & Brisbane & QLD & 4006 & \\
\hline 4 & Royal Brisbane and Women's Hospital & Butterfield Street & Brisbane & QLD & 4029 & \\
\hline 5 & Peter MacCallum Cancer Centre & 305 Grattan St & Melbourne & VIC & 3000 & \\
\hline
\end{tabular}

Postal address of first corresponding author (if different from the institutional address given above)

\begin{tabular}{|l|l|}
\hline Primary Keywords [Office use only] & $\begin{array}{l}\text { Urologic diseases; Neoplasms; Diagnostic techniques and procedures; Surgical } \\
\text { procedures, operative }\end{array}$ \\
\hline Secondary keywords [Office use only] & Prostate; Cancer; Positron emission tomography; Magnetic resonance imaging; Biopsy \\
\hline Notes: &
\end{tabular}

Article details (press ctrl -9 to enter details):

\begin{tabular}{|l|l|}
\hline Article type & Narrative review \\
\hline Blurb & $\begin{array}{l}\text { Prostate cancer continues to be the most } \\
\text { commonly diagnosed cancer, and the } \\
\text { second leading cause of cancer death } \\
\text { among Australian men }\end{array}$ \\
\hline & \\
\hline
\end{tabular}

Office use

\begin{tabular}{|l|l|}
\hline Ms. Number & $\begin{array}{l}\text { mja20.00783. } \\
\text { R2 }\end{array}$ \\
\hline Medical editor & $\begin{array}{l}\text { Francis } \\
\text { Geronimo }\end{array}$ \\
\hline Medical editor email & $\begin{array}{l}\text { fgeronimo@m } \\
\text { ja.com.au }\end{array}$ \\
\hline Structural editor & $\begin{array}{l}\text { Graeme } \\
\text { Prince }\end{array}$ \\
\hline Structural editor email & $\begin{array}{l}\text { gprince@mja. } \\
\text { com.au }\end{array}$ \\
\hline Section/Category & $\begin{array}{l}\text { Narrative } \\
\text { review }\end{array}$ \\
\hline Strapheading & $\begin{array}{l}\text { Narrative } \\
\text { review }\end{array}$ \\
\hline Substrap & . \\
\hline
\end{tabular}

Wiley - file data:

This article is protected by copyright. All rights reserved 


\begin{tabular}{|l|l|}
\hline Filename for copyediting & ong_mja20.00783_ms \\
\hline Accompanying graphics & ong_mja20.00783_gr \\
\hline Stock images & \\
\hline Appendices & \\
\hline
\end{tabular}

Office use - history:

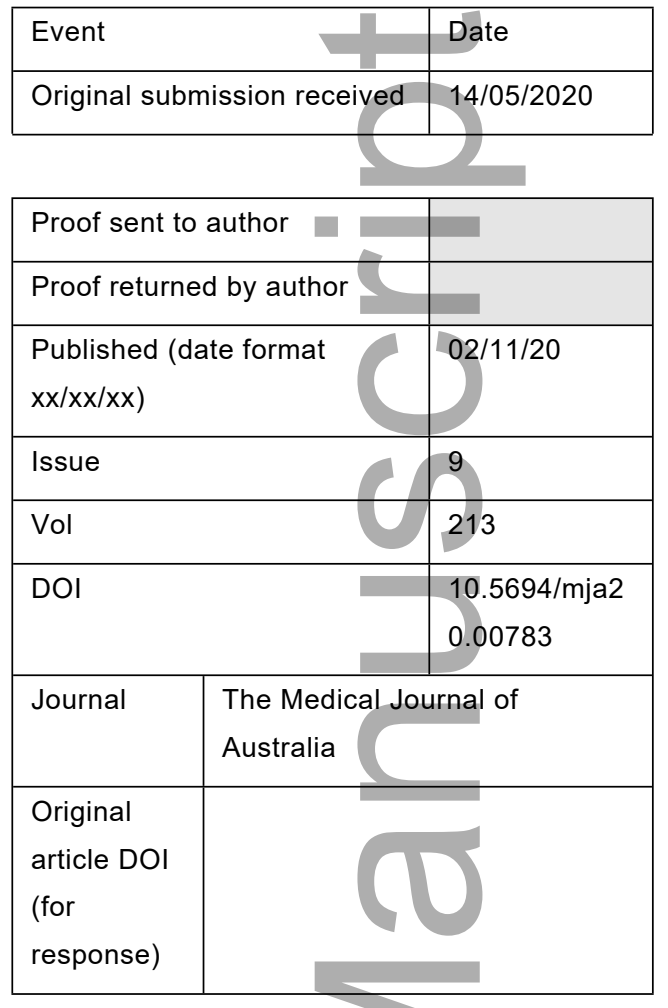

\begin{tabular}{|l|l|}
\hline Event & Date \\
\hline Accept & $16 / 09 / 2020$ \\
\hline
\end{tabular}

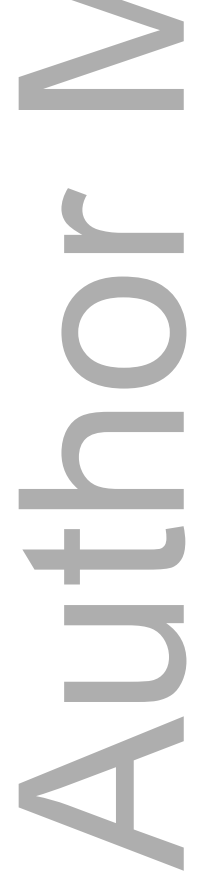

This article is protected by copyright. All rights reserved 


\section{Understanding the diagnosis of}

\section{prostate cancer}

(1

Abstract

— Prostate cancer continues to be the most commonly diagnosed cancer, and the second leading cause of cancer death among Australian men.

- Prostate-specific antigen testing is personalised (not dichotomous in nature) and its interpretation should take into account the patient's age, symptoms, previous results and medication (eg, 5-alpha reductase inhibitors such as dutasteride).

- Multiparametric magnetic resonance imaging of the prostate has been proven to have a 93\% sensitivity for detecting clinically significant prostate cancer. It has the potential to decrease unnecessary prostate biopsies by around $27 \%$.

- International Society of Urological Pathology (ISUP) grade 1 (Gleason score 6) has been shown to have very little, if any, risk of metastasis

- ISUP grade 1 (Gleason score $3+3=6$ ) and low percentage ISUP grade 2 (Gleason score $3+4(<10 \%)=7)$ can be offered active surveillance. The goal of active surveillance is to defer treatment but is still curative when required.

With better imaging (magnetic resonance imaging and emerging prostate-specific membrane antigen positron emission tomography-computed tomography) and transperineal prostate biopsy more men can be offered screening after discussion of risks and benefits, knowing that overdiagnosis has been minimised and radical treatment is reserved for only the most aggressive disease.

With the constant expansion of data and knowledge, the landscape of prostate cancer is continually changing and being refined. ${ }^{1}$ Currently, prostate cancer is estimated to be the most commonly diagnosed cancer among men and the third leading cause of cancer death in Australia. Consequently, there is a wide range of treatments from active surveillance to radical treatments such as surgery and radiation therapy. The challenge for clinicians lies in balancing the early detection of aggressive cancers with the overdiagnosis and treatment of indolent cancers; screening is therefore still largely patient driven and not population based. Further, patient symptoms, comorbidities, lifestyle and autonomy should be taken into account in the creation of a holistic management plan.

In this article, we summarise and discuss the most recent literature and guidelines pertaining to prostate cancer diagnosis and also explore factors that lead to either active surveillance or treatment for low to intermediate risk disease. PubMed, Google Scholar and the Cochrane Library were searched for publications from inception to August 2020 regarding important topics in prostate cancer diagnosis and risk stratification. An emphasis was placed on using evidence from prospective multicentre studies. A combination of published data, current guidelines, expert reviews and our experience was 
then used to formulate a summary of what is applicable in contemporary clinical practice.

\section{Prostate-specific antigen}

Serum prostate-specific antigen (PSA) and digital rectal examination (DRE) are still the fundamentals of prostate cancer investigation and risk stratification. PSA is a protein that is detectable in normal prostate tissue, benign hypertrophic tissue, as well as malignant prostate tissue. $^{3}$ It is therefore not specific for prostate cancer but can be elevated in benign prostatic hyperplasia, prostatitis, after prostate massage, and following prostate biopsy. ${ }^{4}$ Despite this, PSA is still an effective tool in triaging men for diagnostic prostate biopsy. ${ }^{5}$

The interpretation of a PSA result is complex. The PSA threshold of $4 \mathrm{ng} / \mathrm{mL}$ has traditionally been used for detecting prostate cancer ${ }^{5}$ but this has received criticism both for being too high and too low. Thompson and colleagues found that a significant number of men with prostate cancer had a PSA level $<4 \mathrm{ng} / \mathrm{mL}^{6}{ }^{6}$ showing that using a dichotomous PSA result may miss potentially lethal cancer.

PSA is a continuous variable with several factors that affect test results. Age is an important factor when considering a PSA result. A study found median PSA levels to be $0.7 \mathrm{ng} / \mathrm{ml}$ and $0.9 \mathrm{ng} / \mathrm{ml}$ in men aged 40-49 years and 50-59 years, respectively, without diagnosed prostate cancer. ${ }^{7}$ Baseline PSA levels between median and $2.5 \mathrm{ng} / \mathrm{ml}$ were associated with a 14.6-fold and 7.6-fold increased risk of prostate cancer in the respective age groups. ${ }^{7}$ Another study found median PSA was $1.6 \mathrm{ng} / \mathrm{ml}, 1.8 \mathrm{ng} / \mathrm{ml}$ and $2.2 \mathrm{ng} / \mathrm{ml}$ in men aged 70-74 years, 75-79 years and 80-84 years, respectively, without diagnosed prostate caneer. ${ }^{8}$ Age-specific reference ranges have been published and trialled in an attempt to standardise PSA results. ${ }^{9-14}$ However, these should be used with caution as they may potentially miss clinically significant cancers in older men. ${ }^{15}$

Other considerations when interpreting PSA results include use of 5 - $\alpha$ reductase inhibitors (a treatment for benign prostatic hyperplasia), which have been shown to decrease PSA levels by about half. ${ }^{16,17}$ However, instead of simply doubling the PSA result, some studies have shown that 5- $\alpha$ reductase inhibitors and indeed surgical treatment for benign prostatic hyperplasia can increase sensitivity of PSA for prostate cancer detection, ${ }^{18-20}$ so any increase from PSA nadir should prompt further investigation. Prostate size, infection and inflammation can also skew PSA levels. Infection should be treated and PSA retested to obtain an accurate result. ${ }^{21,22}$

Further, PSA density (total PSA/prostate volume) can be taken into consideration for risk assessment. Early results show PSA density may be particularly helpful in decisions for patients with equivocal magnetic resonance imaging (MRI) results. ${ }^{23}$ Of note, PSA kinetics - velocity (difference in PSA per year) and doubling time (number of months for PSA to double) - have a more prominent role in relapsed and advanced prostate cancer; however, at this stage there is no evidence supporting its use in diagnosis. ${ }^{24}$ 


\section{Free-to-total PSA ratio and Prostate Health Index}

Isoforms of PSA have been investigated to improve PSA specificity while maintaining sensitivity for predicting prostate cancer. Patients with prostate cancer have been shown to have higher protein-bound PSA and lower free PSA. ${ }^{25}$ This was validated in a multicentre prospective study which found that a score of $<25 \%$ free-to-total PSA detected $95 \%$ of cancers while avoiding $25 \%$ of unnecessary biopsies. The score was also an independent predictor of prostate cancer on multivariate analysis (odds ratio, 3.2; $95 \%$ CI, 2.5-4.1; $P<0.001$ ) compared with total PSA by itself (odds ratio, 1.0; 95\% CI, 0.921.11). ${ }^{26}$ Importantly, this study only included men with PSA levels of $4-10 \mathrm{ng} / \mathrm{mL}$ and a negative DRE result.

Other isoforms including proPSA, intact PSA and benign PSA have been described and incorporated to form algorithms for diagnosis. The Prostate Health Index (PHI) ${ }^{27}$ is most commonly used, while others are very expensive and unavailable in Australia (eg, the $4 \mathrm{~K}$ score). PHI is a mathematical score which uses three isoforms of PSA to predict the probability of prostate cancer on biopsy. The $4 \mathrm{~K} \operatorname{score}^{28}$ is a score based on four PSA isoforms and also encompasses DRE, age and previous biopsy results if available. A recent systematic review and meta-analysis showed that the pooled sensitivity for all studies was 0.89 and 0.74 for $\mathrm{PHI}$ and $4 \mathrm{~K}$ score, respectively. ${ }^{29}$ However, using algorithms to reduce unnecessary biopsies from analysis of a simple blood test has not translated to routine use in Australia.

\section{Guidelines for PSA screening}

PSA screening is a highly debated topic and applies to men who are asymptomatic with no previous diagnosis of prostate cancer. Guidelines currently recommend against population-based screening and state that men must be well informed of the risks of prostate cancer investigation (Box 1) before proceeding. ${ }^{30-32}$ Box 2 summarises the European, United States and Australian guidelines on PSA screening.

\section{Guidelines for PSA testing}

European guidelines acknowledge PSA as a continuous variable with no agreed defined standards and recommend offering risks calculators (PHI or $4 \mathrm{~K}$ score), imaging or additional urine- or serum-based biomarkers for patients with a PSA level of 2-10 ng/mL and a normal DRE result to avoid unnecessary biopsy. They also caution against the use of free PSA because it can be affected by several pre-analytical and clinical variables. ${ }^{30}$

Australian guidelines use $3 \mathrm{ng} / \mathrm{mL}$ as a threshold for offering a repeat PSA test (recommended to be performed within 1-3 months), then recommend offering biopsy for patients with PSA levels $>5.5 \mathrm{ng} / \mathrm{mL}$, or $3-5.5 \mathrm{ng} / \mathrm{mL}$ with free-to-total PSA $<25 \%$ on repeat test. PSA velocity and PHI are not recommended as adjuncts to PSA. ${ }^{32}$ 


\section{Digital rectal examination}

Even in the PSA testing era, DRE still provides valuable information in the diagnosis and staging of prostate cancer. ${ }^{33}$ Its utility, however, is clinician dependent and difficult to standardise. Often DRE is not sufficiently taught in medical school and clinicians who do not perform many DREs may not have the confidence or skills to perform it effectively. ${ }^{34}$ Australian guidelines do not recommended DRE as a routine addition to PSA testing in asymptomatic men; however, DRE can be performed at a clinician's discretion. ${ }^{32}$ The DRE will remain an important part of diagnosis as it can detect some cancers even in patients with low PSA levels. ${ }^{35,36}$

\section{Multiparametric MRI of the prostate}

Multiparametric MRI has revolutionised the prostate cancer diagnostic pathway in the past decade. Previously, prostate cancer diagnosis relied on an elevated PSA level and subsequent transrectal ultrasound-guided (TRUS) biopsy. Prostate multiparametric MRI is now used as the initial evaluation of an elevated PSA level and has resulted in a decrease of many "unnecessary benign" biopsies ${ }^{37}$ while also improving the accuracy of prostate biopsy results.

The diagnostic strengths of multiparametric MRI have been well documented in recent practice-changing studies. A large, prospective, multicentre study compared the diagnostic accuracy of multiparametric MRI and TRUS biopsy. For detecting clinically significant Gleason scores $\geq 7$ (see below for an explanation of Gleason scoring), prostate cancer multiparametric MRI had a sensitivity of $87 \%$ and negative predictive value of $72 \%$, both of which outperformed TRUS biopsy (sensitivity, 60\%; negative predictive value, $65 \%){ }^{38}$ TRUS biopsy still had higher specificity and positive predictive value compared with multiparametric MRI, indicating that biopsy is still needed following multiparametric MRI to confirm cancer. The main outcome from this study showed that if patients received a multiparametric MRI before biopsy then this might allow $27 \%$ of men to avoid an unnecessary primary biopsy and increase the detection of clinically significant cancers by $18 \% .^{38}$

The ability to locate the suspected prostate cancer lesion with multiparametric MRI has allowed more targeted biopsy techniques, which has improved the accuracy of biopsy results. Previously, TRUS biopsies were performed in a systematic grid-like fashion but had potential adverse effects such as infection or urosepsis, and significant false negative rates of $30-40 \% \cdot{ }^{39,40}$ An international, multicentre randomised trial compared MRItargeted with standard biopsy for prostate cancer diagnosis. ${ }^{41}$ The results showed that the detection rate of clinically significant cancer (defined as Gleason score $\geq 7$ ) with MRItargeted biopsy was $12 \%$ higher than with standard biopsy. Moreover, the detection rate of clinically insignificant cancer (defined as Gleason score $\leq 6$ ) was $13 \%$ less than standard biopsy. The MRI-targeted biopsy arm had a median of four core biopsies taken compared with 12 in the standard biopsy arm. ${ }^{41}$ Overall, this revealed that under- and 
overdiagnosis was reduced with an MRI-triaged target biopsy with less cores needed for this increased accuracy.

The utility of a multiparametric MRI lesion for predicting clinically significant prostate cancer has now been classified using the prostate imaging reporting and data system yersion 2 (PI-RADS v2) (Box 3). ${ }^{42}$ Analysis of PI-RADS v2 compared with histological results have shown that this scoring system has a lower sensitivity for low volume, low grade disease and may also be a predictor of downgrading from a Gleason score of $3+4=7$ from biopsy to a score of $3+3=6$ at prostatectomy. ${ }^{43-45}$ For larger, more suspicious multiparametric MRI lesions (PI-RADS v2 score, 4-5), PI-RADSv2 was shown to be a predictor of clinically significant cancer with a sensitivity and specificity of $73.7-77.0 \%$ and $71.4-77.3 \%$, respectively. ${ }^{46}$

The importance of multiparametric MRI has been recognised globally. Current guidelines suggest that multiparametric MRI be used for patients to aid in decision making for biopsy or repeat biopsy. ${ }^{30,32}$ In Australia, this has culminated in governmentsubsidised multiparametric MRI for patients with suspicion of prostate cancer for diagnosis (Box 4).

\section{Transperineal biopsy of the prostate}

For many years, traditional TRUS-guided biopsy broke the fundamental surgical principle of sterile technique by passing the biopsy needle through "dirty" rectal mucosa to reach the prostate, leading to increased post biopsy infection rates of up to $10 \% .{ }^{47}$ The new transperineal biopsy technique dramatically decreases this potentially fatal complication. ${ }^{48,49}$

The transperineal approach is a guided approach of the biopsy needle through sterilised perineal skin into the prostate, which completely avoids rectal flora. This technique has been shown to decrease infection rates to almost zero ${ }^{48,49}$ while maintaining at accuracy at least as high as TRUS biopsy. ${ }^{50}$ Further, the risk of complications can be further decreased, as transperineal biopsy can also be performed under local anaesthetic with good effect. ${ }^{51}$ Such factors prompted a recent call for transperineal biopsy to become the new standard of care. ${ }^{52}$ In Australia, and much of the world, this transition is widely recognised, with many urology units already implementing or looking to implement this technique in routine clinical practice. ${ }^{52}$

\section{Grading of prostate cancer}

Gleason score remains the mainstay of histological classification for prostate cancer.

Donald Gleason first described the scoring system in 1966. He detailed and summarised the patterns of glandular differentiation seen on histological staining and developed a scoring system of patterns from 1 to 5 . The two most predominant patterns seen were added together to give a final Gleason score $(\mathrm{eg}$, Gleason $3+4=7) .{ }^{53}$ The Gleason score 
is now included in most guidelines globally and is endorsed by the World Health Organization as the standard approach to histological grading. ${ }^{54}$

In addition to the Gleason score, the International Society of Urological Pathology (ISUP) 2014 consensus accepted a prognostic five-grade system (Box 5), ${ }^{55}$ to give patients a better understanding of aggressiveness and risk of progression. The ISUP grade has also been referred to as grade-group by some pathologists, which can be confusing. Nevertheless, the ISUP grade or grade-group categorises Gleason scoring into five distinct prognostic groups. ${ }^{55}$ What the ISUP grade better illustrates is that Gleason 6 out of 10 cancer (ISUP grade 1) is a less aggressive form of cancer with a small risk of progression. It also indicates that Gleason 7 out of 10 cancer can be split into to two prognostically different cancers (ISUP grade 2 and 3). ${ }^{56}$

\section{Active surveillance}

Gleason pattern 3 cancer has different genomic properties compared with Gleason pattern 4 and $5 .{ }^{57}$ Gleason score $3+3=6$ cancer has a low metastatic potential and a very low risk of mortality. A study of 14123 cases found that zero cases of Gleason score 6 cancer had lymph node metastases at radical prostatectomy. ${ }^{58}$ Another study of 12389 cases reported a $0.2 \%$ 15-year prostate specific cancer mortality rate for Gleason scores $<6$ (ISUP grade 1) after a radical prostatectomy. This knowledge forms the foundation of the modern day initial approach of active surveillance protocols for Gleason $3+3$ malignancy.

Active surveillance combines PSA, DRE and prostate biopsy to closely monitor a patient's prostate cancer, with the conversion to active treatment if progression occurs. ${ }^{30}$ It is a highly debated topic and is the subject of much research. Criteria for inclusion include patients with ISUP grade 1 disease, PSA levels $<20 \mathrm{ng} / \mathrm{mL}$, and clinically localised disease tumour stage (1-2). Contemporary criteria also include some ISUP grade 2 patients with low percentage of Gleason pattern $4(<10 \%)$. Other factors to consider are the volume of cancer and number of biopsy cores taken. Early results suggest multiparametrie MRI results also have a role for inclusion and monitoring of patients on active surveillance. ${ }^{59}$ Patient autonomy, comorbidities and life expectancy also need to be taken into account. Clearly, there are many variables that inform the decision for active surveillance and there are no standardised inclusion criteria. Therefore, this decision should be made by a specialist with experience.

Regarding protocols for active surveillance, after initial investigations and confirmatory biopsy, men should receive 6-montly PSA testing and DRE, and further biopsy every 1-3 years depending on level of suspicion. ${ }^{32}$ However, this is a dynamic space which will change with more prostate imaging experience and longer follow-up of active surveillance cohorts. 


\section{Prostate-specific membrane antigen positron emission tomography- computed tomography}

Prostate-specific membrane antigen (PSMA) is a type 2 transmembrane glycoprotein expressed in prostate tissue as well as salivary glands, lacrimal glands, renal tubular cells and the small intestine. Its expression has been shown to be increased in prostate cancer, particularly in higher grade metastatic disease, making it a good biological target for detecting smaller lesions. In Australia, PSMA positron emission tomography-computed tomography (PET-CT) scans are widely available, enabling the running of the largest randomised controlled trial of PSMA PET-CT to date, ${ }^{60}$ which demonstrated its superiority for primary staging compared with conventional scans (CT scan of the abdomen and pelvis and whole body bone scan).

The accuracy of PSMA PET-CT for characterising cancer within the prostate and its role in diagnosis of prostate cancer is currently in the early stages of investigation. A retrospective study of 205 men found no difference between PSMA PET-CT and multiparametric MRI in detecting all primary tumours, clinically significant tumours or transition zone tumours. ${ }^{61}$ Another study also found PSMA PET-CT to have greater sensitivity, specificity, negative predictive value and positive predictive value in intermediate grade cancers (ISUP grade 2-3) compared with multiparametric MRI; a combination of the two modalities increased accuracy slightly. ${ }^{62}$ Comparing the concordance between biopsy and radical prostatectomy histology in 144 men, PSMA PET-CT was found to incrementally improve tumour location compared with multiparametric MRI. ${ }^{63}$

The PRIMARY trial seeks to identify the value of PSMA PET-CT in detecting clinically significant prostate cancer in men undergoing initial biopsy. This is an Australian-led multicentre, prospective, cross-sectional study investigating pelvic-only PSMA PET-CT in combination with multiparametric MRI against targeted prostate biopsies. It aims to recruit 600 men to provide level 1 evidence about imaging accuracy, the avoidance of overdiagnosis, and health economic analysis of pelvic-only PSMA PETCT in the diagnostic setting. ${ }^{64}$

\section{A multidisciplinary approach}

Given its complex nature, the search for improved outcomes has been somewhat of a call to arms, with many health specialties banding together to progress the development of prostate cancer management. Men diagnosed with prostate cancer are extensively discussed in multidisciplinary forums where radiologists, nurses, urologists, radiation oncologists and medical oncologists may all partake in offering decision choices. These meetings have been shown to make high impact changes for around one-quarter of cases, especially in patients with advanced cancer. ${ }^{65}$ Multidisciplinary meetings also facilitate cross-referrals from specialty to specialty in a timely, upfront manner. ${ }^{65}$ The nature of multidisciplinary meetings allows for a holistic approach to patient care and management, with experts from many fields providing knowledge that influences decision making. 


\section{Conclusion}

The diagnosis and risk stratification of prostate cancer has seen major advancements in technology and changes in patterns of care in diagnosis and management over the past two decades (Box 6). New imaging modalities, risk calculators, biopsy techniques and management strategies have created an arsenal of information to aid in clinical decision making. The dilemma of overdiagnosis and overtreatment in Australia has decreased over the last decade but continues to hold back more widespread screening. The avoidance of unnecessary biopsies by imaging and the implementation of active surveillance for men with lower risk disease have emerged as a way to combat this problem. Men and their medical practitioners need to revisit prostate cancer in light of this new contemporary landscape.

Competing interests: No relevant disclosures.

Provenance: Commissioned; externally peer reviewed.

\section{Author details}

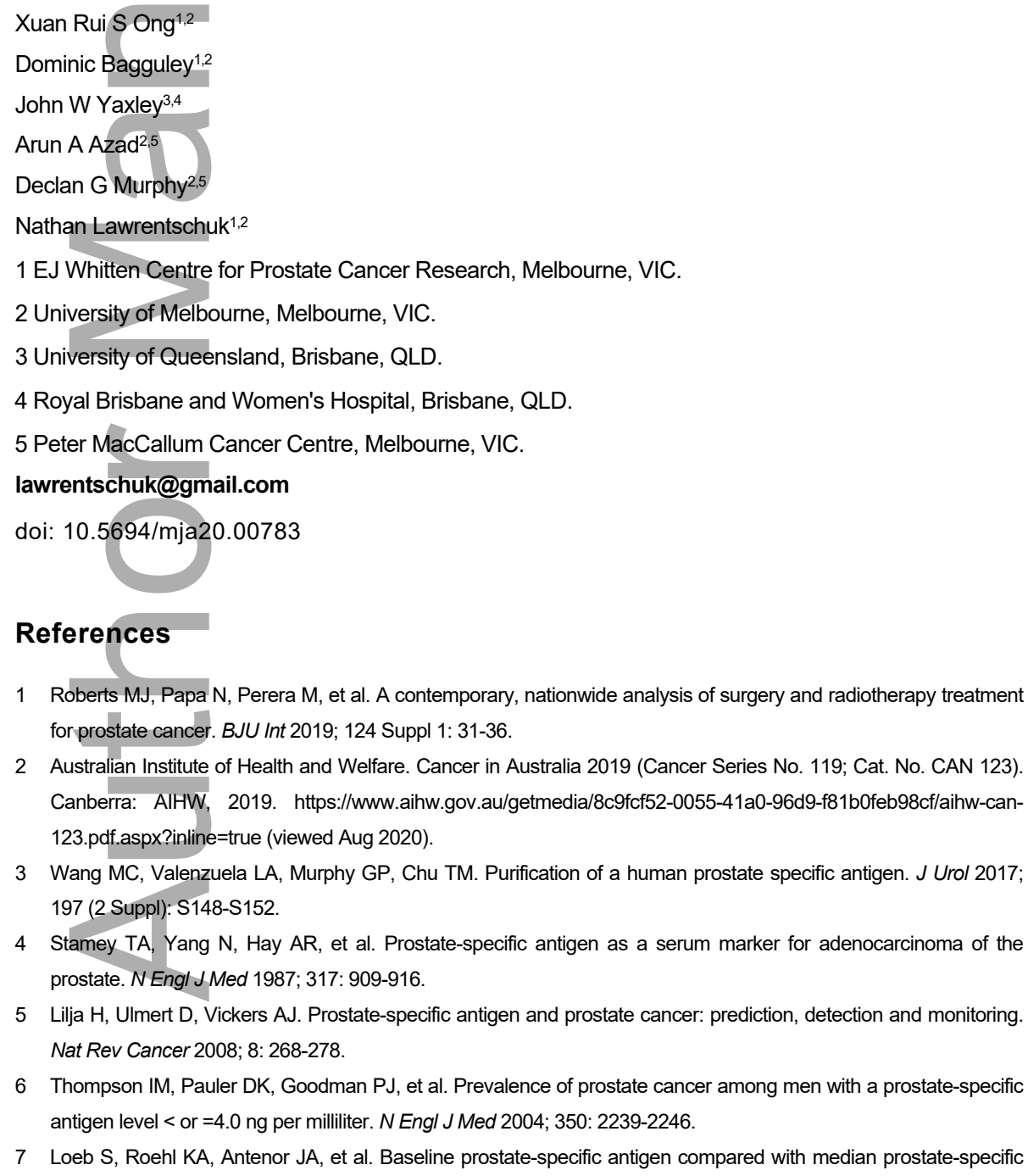

\section{References}

1 Roberts MJ, Papa N, Perera M, et al. A contemporary, nationwide analysis of surgery and radiotherapy treatment for prostate cancer. BJU Int 2019; 124 Suppl 1: 31-36.

2 Australian Institute of Health and Welfare. Cancer in Australia 2019 (Cancer Series No. 119; Cat. No. CAN 123). Canberra: AlHW, 2019. https://www.aihw.gov.au/getmedia/8c9fcf52-0055-41a0-96d9-f81b0feb98cf/aihw-can123.pdf.aspx?inline=true (viewed Aug 2020).

3 Wang MC, Valenzuela LA, Murphy GP, Chu TM. Purification of a human prostate specific antigen. J Urol 2017; 197 (2 Suppl): S148-S152.

4 Stamey TA, Yang N, Hay AR, et al. Prostate-specific antigen as a serum marker for adenocarcinoma of the prostate. NEngl J Med 1987; 317: 909-916.

5 Lilja H, Ulmert D, Vickers AJ. Prostate-specific antigen and prostate cancer: prediction, detection and monitoring. Nat Rev Cancer 2008; 8: 268-278.

6 Thompson IM, Pauler DK, Goodman PJ, et al. Prevalence of prostate cancer among men with a prostate-specific antigen level < or =4.0 ng per milliliter. N Engl J Med 2004; 350: 2239-2246.

7 Loeb S, Roehl KA, Antenor JA, et al. Baseline prostate-specific antigen compared with median prostate-specific 
antigen for age group as predictor of prostate cancer risk in men younger than 60 years old. Urology 2006; 67 : 316-320.

8 Litchfield MJ, Cumming RG, Smith DP, et al. Prostate-specific antigen levels in men aged 70 years and over: findings from the CHAMP study. Med J Aust 2012; 196: 395-398. https://www.mja.com.au/journal/2012/196/6/prostate-specific-antigen-levels-men-aged-70-years-and-overfindings-champ-study

9 Oesterling JE, Jacobsen SJ, Chute CG, et al. Serum prostate-specific antigen in a community-based population of healthy men. Establishment of age-specific reference ranges. JAMA 1993; 270: 860-864.

10 Morgan TO, Jacobsen SJ, McCarthy WF, et al. Age-specific reference ranges for serum prostate-specific antigen in black men. N Engl J Med 1996; 335: 304-310.

11 Partin AW, Criley SR, Subong EN, et al. Standard versus age-specific prostate specific antigen reference ranges among men with clinically localized prostate cancer: a pathological analysis. J Urol 1996; 155: 1336-1339.

12 DeAntoni EP, Crawford ED, Oesterling JE, et al. Age- and race-specific reference ranges for prostate-specific antigen from a large community-based study. Urology 1996; 48: 234-239.

13 Anderson JR, Strickland D, Corbin D, et al. Age-specific reference ranges for serum prostate-specific antigen. Urology 1995; 46: 54-57.

Oesterling JE, Jacobsen SJ, Klee GG, et al. Free, complexed and total serum prostate specific antigen: the establishment of appropriate reference ranges for their concentrations and ratios. J Urol 1995; 154: 1090-1095.

15 Borer JG, Sherman J, Solomon MC, et al. Age specific prostate specific antigen reference ranges: population specific. J Urol 1998; 159: 444-448.

16 D'Amico AV, Roehrborn CG. Effect of $1 \mathrm{mg} /$ day finasteride on concentrations of serum prostate-specific antigen in men with androgenic alopecia: a randomised controlled trial. Lancet Oncol 2007; 8: 21-25

17 Marks LS, Andriole GL, Fitzpatrick JM, et al. The interpretation of serum prostate specific antigen in men receiving 5alpha-reductase inhibitors: a review and clinical recommendations. J Urol 2006; 176: 868-74.

18 Marks LS, Andriole GL, Fitzpatrick JM, et al. The interpretation of serum prostate specific antigen in men receiving 5a-reductase inhibitors: a review and clinical recommendations. J Urol 2006; 176: 868-874.

19 Thompson IM, Chi C, Ankerst DP, et al. Effect of finasteride on the sensitivity of PSA for detecting prostate cancer. J Natl Cancer Inst 2006; 98: 1128-1133.

20 Helfand BT, Anderson CB, Fought A, et al. Postoperative PSA and PSA velocity identify presence of prostate cancer after various surgical interventions for benign prostatic hyperplasia. Urology 2009; 74: 177-183.

21 Nadler RB, Humphrey PA, Smith DS, et al. Effect of inflammation and benign prostatic hyperplasia on elevated serum prostate specific antigen levels. J Urol 1995; 154 (2 Pt 1): 407-413.

22 Neal DE, Jr., Clejan S, Sarma D, Moon TD. Prostate specific antigen and prostatitis. I. Effect of prostatitis on serum PSA in the human and nonhuman primate. Prostate 1992; 20: 105-111.

23 Washino S, Okochi T, Saito K, et al. Combination of prostate imaging reporting and data system (PI-RADS) score and prostate-specific antigen (PSA) density predicts biopsy outcome in prostate biopsy naïve patients. BJU Int 2017; 119: 225-233.

Vickers AJ, Brewster SF. PSA velocity and doubling time in diagnosis and prognosis of prostate cancer. $\mathrm{Br} \mathrm{J} \mathrm{Med}$ Surg Urol 2012; 5: 162-168.

25 Pannek J, Rittenhouse HG, Chan DW, et al. The use of percent free prostate specific antigen for staging clinically localized prostate cancer. J Urol 1998; 159: 1238-1242.

26 Catalona WJ, Partin AW, Slawin KM, et al. Use of the percentage of free prostate-specific antigen to enhance differentiation of prostate cancer from benign prostatic disease: a prospective multicenter clinical trial. JAMA 1998; 279: 1542-1547.

27 Catalona WJ, Partin AW, Sanda MG, et al. A multicenter study of [-2] pro-prostate specific antigen combined with prostate specific antigen and free prostate specific antigen for prostate cancer detection in the 2.0 to $10.0 \mathrm{ng} / \mathrm{ml}$ prostate specific antigen range. J Urol 2011; 185: 1650-1655.

28 Vickers AJ, Cronin AM, Aus G, et al. A panel of kallikrein markers can reduce unnecessary biopsy for prostate cancer: data from the European Randomized Study of Prostate Cancer Screening in Göteborg, Sweden. BMC Med 2008; 6: 19

29 Russo GI, Regis F, Castelli T, et al. A systematic review and meta-analysis of the diagnostic accuracy of Prostate Health Index and 4-kallikrein panel score in predicting overall and high-grade prostate cancer. Clin Genitourin Cancer 2017; 15: 429-439.e1.

30 Mottet N, van den Bergh R, Briers E. EAU-EANM-ESTRO-ESUR-SIOG guidelines on prostate cancer. Eur Urol 2019; 75: 889-890. 
31 Grossman DC, Curry SJ, Owens DK, et al. Screening for prostate cancer: US Preventive Services Task Force recommendation statement. JAMA 2018; 319: 1901-1913.

32 Prostate Cancer Foundation of Australia and Cancer Council Australia. Clinical practice guidelines for PSA testing and early management of test-detected prostate cancer. 2015. https://wiki.cancer.org.au/australia/Guidelines:PSA_Testing (viewed Aug 2020).

33 Catalona WJ, Richie JP, Ahmann FR, et al. Comparison of digital rectal examination and serum prostate specific antigen in the early detection of prostate cancer: results of a multicenter clinical trial of 6,630 men. $J$ Urol 2017; 197 (2 Suppl): S200-S207.

34 Patel MI, Kakala B, Beattie K. Teaching medical students digital rectal examination: a randomized study of simulated model vs rectal examination volunteers. BJU Int 2019; 124 Suppl 1: 14-18.

35 Schröder $\mathrm{FH}$, Kruger $\mathrm{AB}$, Rietbergen J, et al. Evaluation of the digital rectal examination as a screening test for prostate cancer. J Natl Cancer Inst 1998; 90: 1817-1823.

36 Carvalhal GF, Smith DS, Mager DE, et al. Digital rectal examination for detecting prostate cancer at prostate specific antigen levels of $4 \mathrm{ng} / \mathrm{ml}$ or less. J Urol 1999; 161: 835-839.

37 Thompson J, Van Leeuwen P, Moses D, et al. The diagnostic performance of multiparametric magnetic resonance imaging to detect significant prostate cancer. J Urol 2016; 195: 1428-1435.

38 Ahmed HU, El-Shater Bosaily A, Brown LC, et al. Diagnostic accuracy of multi-parametric MRI and TRUS biopsy in prostate cancer (PROMIS): a paired validating confirmatory study. Lancet 2017; 389: 815-822.

$39 \mathrm{Hu}$ Y, Ahmed HU, Carter T, et al. A biopsy simulation study to assess the accuracy of several transrectal ultrasonography (TRUS)-biopsy strategies compared with template prostate mapping biopsies in patients who have undergone radical prostatectomy. BJU Int 2012; 110: 812-820.

40 Norberg M, Egevad L, Holmberg L, et al. The sextant protocol for ultrasound-guided core biopsies of the prostate underestimates the presence of cancer. Urology 1997; 50: 562-566.

41 Kasivisvanathan V, Rannikko AS, Borghi M, et al. MRI-targeted or standard biopsy for prostate-cancer diagnosis. N Engl J Med 2018; 378: 1767-1777.

42 Weinreb JC, Barentsz JO, Choyke PL, et al. PI-RADS prostate imaging - reporting and data system: 2015, version 2. Eur Urol 2016; 69: 16-40.

43 Park SY, Jung DC, Oh YT, et al. Prostate cancer: PI-RADS version 2 helps preoperatively predict clinically significant cancers. Radiology 2016; 280: 108-116.

44 Padhani AR, Weinreb J, Rosenkrantz AB, et al. Prostate Imaging-Reporting and Data System Steering Committee: PI-RADS v2 status update and future directions. Eur Urol 2019; 75: 385-396.

45 Woo S, Kim SY, Lee J, et al. PI-RADS version 2 for prediction of pathological downgrading after radical prostatectomy: a preliminary study in patients with biopsy-proven Gleason Score $7(3+4)$ prostate cancer. Eur Radiol 2016; 26: 3580-3587.

46 Hansen NL, Barrett T, Kesch C, et al. Multicentre evaluation of magnetic resonance imaging supported transperineal prostate biopsy in biopsy-naïve men with suspicion of prostate cancer. BJU Int 2018; 122: 40-49.

47 Wei TC, Lin TP, Chang YH, et al. Transrectal ultrasound-guided prostate biopsy in Taiwan: A nationwide database study. J Chin Med Assoc 2015; 78: 662-665.

48 Grummet JP, Weerakoon M, Huang S, et al. Sepsis and 'superbugs': should we favour the transperineal over the transrectal approach for prostate biopsy? BJU Int 2014; 114: 384-388.

49 Symons JL, Huo A, Yuen CL, et al. Outcomes of transperineal template-guided prostate biopsy in 409 patients. BJU Int 2013; 112: 585-593.

50 Yaxley AJ, Yaxley JW, Thangasamy IA, et al. Comparison between target magnetic resonance imaging (MRI) ingantry and cognitively directed transperineal or transrectal-guided prostate biopsies for Prostate ImagingReporting and Data System (PI-RADS) 3-5 MRI lesions. BJU Int 2017; 120 Suppl 3: 43-50.

51 Stefanova V, Buckley R, Flax S, et al. Transperineal prostate biopsies using local anesthesia: experience with 1,287 patients. prostate cancer detection rate, complications and patient tolerability. J Urol 2019; 201: 1121-1126.

52 Grummet J, Gorin MA, Popert R, et al. "TREXIT 2020”: why the time to abandon transrectal prostate biopsy starts now. Prostate Cancer Prostatic Dis 2020; 23: 62-65.

53 Gleason DF, Mellinger GT. Prediction of prognosis for prostatic adenocarcinoma by combined histological grading and clinical staging. J Urol 2017; 197 (2 Suppl): S134-S139.

54 Humphrey PA, Moch H, Cubilla AL, et al. The 2016 WHO classification of tumours of the urinary system and male genital organs - Part B: prostate and bladder tumours. Eur Urol 2016; 70: 106-119.

55 Epstein JI, Egevad L, Amin MB, et al. The 2014 International Society of Urological Pathology (ISUP) Consensus Conference on Gleason Grading of Prostatic Carcinoma: definition of grading patterns and proposal for a new 
grading system. Am J Surg Pathol 2016; 40: 244-252.

56 Epstein JI, Zelefsky MJ, Sjoberg DD, et al. A contemporary prostate cancer grading system: a validated alternative to the Gleason score. Eur Urol 2016; 69: 428-435.

57 Ross AE, Marchionni L, Vuica-Ross M, et al. Gene expression pathways of high grade localized prostate cancer. Prostate 2011; 71: 1568-1577.

58 Ross HM, Kryvenko ON, Cowan JE, et al. Do adenocarcinomas of the prostate with Gleason score (GS) $\leq 6$ have the potential to metastasize to lymph nodes? Am J Surg Pathol 2012; 36: 1346-1352.

59 Amin A, Scheltema MJ, Shnier R, et al. The Magnetic Resonance Imaging in Active Surveillance (MRIAS) trial: use of baseline multiparametric magnetic resonance imaging and saturation biopsy to reduce the frequency of surveillance prostate biopsies. J Urol 2020; 203: 910-917.

60 Hofman MS, Lawrentschuk N, Francis RJ, et al. Prostate-specific membrane antigen PET-CT in patients with high-risk prostate cancer before curative-intent surgery or radiotherapy (proPSMA): a prospective, randomised, multicentre study. Lancet 2020; 395: 1208-1216.

61 Kalapara AA, Nzenza T, Pan HYC, et al. Detection and localisation of primary prostate cancer using (68) gallium prostate-specific membrane antigen positron emission tomography/computed tomography compared with multiparametric magnetic resonance imaging and radical prostatectomy specimen pathology. BJU Int 2020; 126 : 83-90.

2 Scheltema MJ, Chang JI, Stricker PD, et al. Diagnostic accuracy of 68Ga-prostate-specific membrane antigen (PSMA) positron-emission tomography (PET) and multiparametric $(\mathrm{mp}) \mathrm{MRI}$ to detect intermediate-grade intra-prostatic prostate cancer using whole-mount pathology: impact of the addition of 68Ga-PSMA PET to mp MRI. BJU Int 2019; 124: 42-49.

63 Donato P, Morton A, Yaxley J, et al. (68)Ga-PSMA PET/CT better characterises localised prostate cancer after MRI and transperineal prostate biopsy: is (68)Ga-PSMA PET/CT guided biopsy the future? Eur J Nucl Med Mol Imaging 2020; 47: 1843-1851.

64 Amin A, Blazevski A, Thompson J, et al. Protocol for the PRIMARY clinical trial, a prospective, multicentre, cross-sectional study of the additive diagnostic value of gallium-68 prostate-specific membrane antigen positron-emission tomography/computed tomography to multiparametric magnetic resonance imaging in the diagnostic setting for men being investigated for prostate cancer. BJU Int 2020; 125: 515-524.

65 Rao K, Manya K, Azad A, et al. Uro-oncology multidisciplinary meetings at an Australian tertiary referral centreimpact on clinical decision-making and implications for patient inclusion. BJU Int 2014; 114: 50-54.

[Boxes]

\section{Risks of early detection of prostate cancer}

Overdiagnosis - diagnosis of prostate cancer that would never have become symptomatic in the patient's lifetime

- Potential complications from diagnostic prostate biopsy - pain, infection

- Overtreatment - treatment of prostate cancer that would never have become symptomatic in the patient's lifetime

Potential complications from curative treatment - erectile dysfunction, urinary incontinence, bowel symptoms

Psychological harms 
2 Guidelines for prostate-specific antigen (PSA) screening

\begin{tabular}{|c|c|c|c|}
\hline & $\begin{array}{l}\text { European Association of } \\
\text { Urology } \\
30\end{array}$ & $\begin{array}{l}\text { US Preventative Services } \\
\text { Task Force }^{31}\end{array}$ & $\begin{array}{l}\text { Prostate Cancer } \\
\text { Foundation of Australia }{ }^{32}\end{array}$ \\
\hline $\begin{array}{l}\text { Who to offer PSA } \\
\text { screening }\end{array}$ & $\begin{array}{l}\text { Well informed men with at } \\
\text { least } 10-15 \text { years' life }\end{array}$ & $\begin{array}{l}\text { Well informed men aged } \\
50-69 \text { years }\end{array}$ & $\begin{array}{l}\text { Well informed men aged } \\
45-69 \text { years }\end{array}$ \\
\hline $\begin{array}{l}\text { Who not to offer } \\
\text { screening }\end{array}$ & $\begin{array}{l}\text { Men with }<15 \text { years life } \\
\text { expectancy }- \text { unlikely to } \\
\text { benefit }\end{array}$ & Men aged $>70$ years & Men aged $>70$ years \\
\hline Early PSA screening & $\begin{array}{l}\text { Well informed men at } \\
\text { elevated risk of prostate } \\
\text { cancer aged }>50 \text { years; } \\
\text { aged }>45 \text { years with family } \\
\text { history of prostate cancer; or } \\
\text { African-Americans aged }>45 \\
\text { years }\end{array}$ & na & $\begin{array}{l}\text { Well informed men aged } \\
45-69 \text { years estimated to } \\
\text { be } 2.5-3 \text { times higher } \\
\text { than average risk* } \\
\text { Well informed men aged } \\
40-69 \text { years estimated to } \\
\text { be } 9-10 \text { times higher than }^{*} \\
\text { average risk }{ }^{\dagger}\end{array}$ \\
\hline How often to screen & Individualised strategy & na & PSA test every 2 years \\
\hline
\end{tabular}

* Due to presence of risk factors such as a brother diagnosed with prostate cancer, particularly if diagnosed at $<60$ years of age. $†$ Due to presence of risk factors such as father and two brothers diagnosed with prostate cancer.

$\begin{aligned} & 3 \text { Prostate imaging reporting and data system (PI-RADS) version 2: five-point } \\
& \text { scale for the likelihood of multiparametric magnetic resonance imaging } \\
& \text { predicting clinically significant prostate cancer }{ }^{42}\end{aligned}$
\begin{tabular}{lll} 
Category & Likelihood & Clinical significance \\
\hline PI-RADS 1 & Very low & Clinically significant cancer is highly unlikely to be present \\
PI-RADS 2 & Low & Clinically significant cancer is unlikely to be present \\
PI-RADS 3 & Intermediate & Presence of clinically significant cancer is equivocal \\
PI-RADS 4 & High & Clinically significant cancer is likely to be present \\
PI-RADS 5 & Very high & Clinically significant cancer is highly likely to be present
\end{tabular}

This article is protected by copyright. All rights reserved 


\section{Prostate cancer diagnostic tests: Medicare rebate availability}

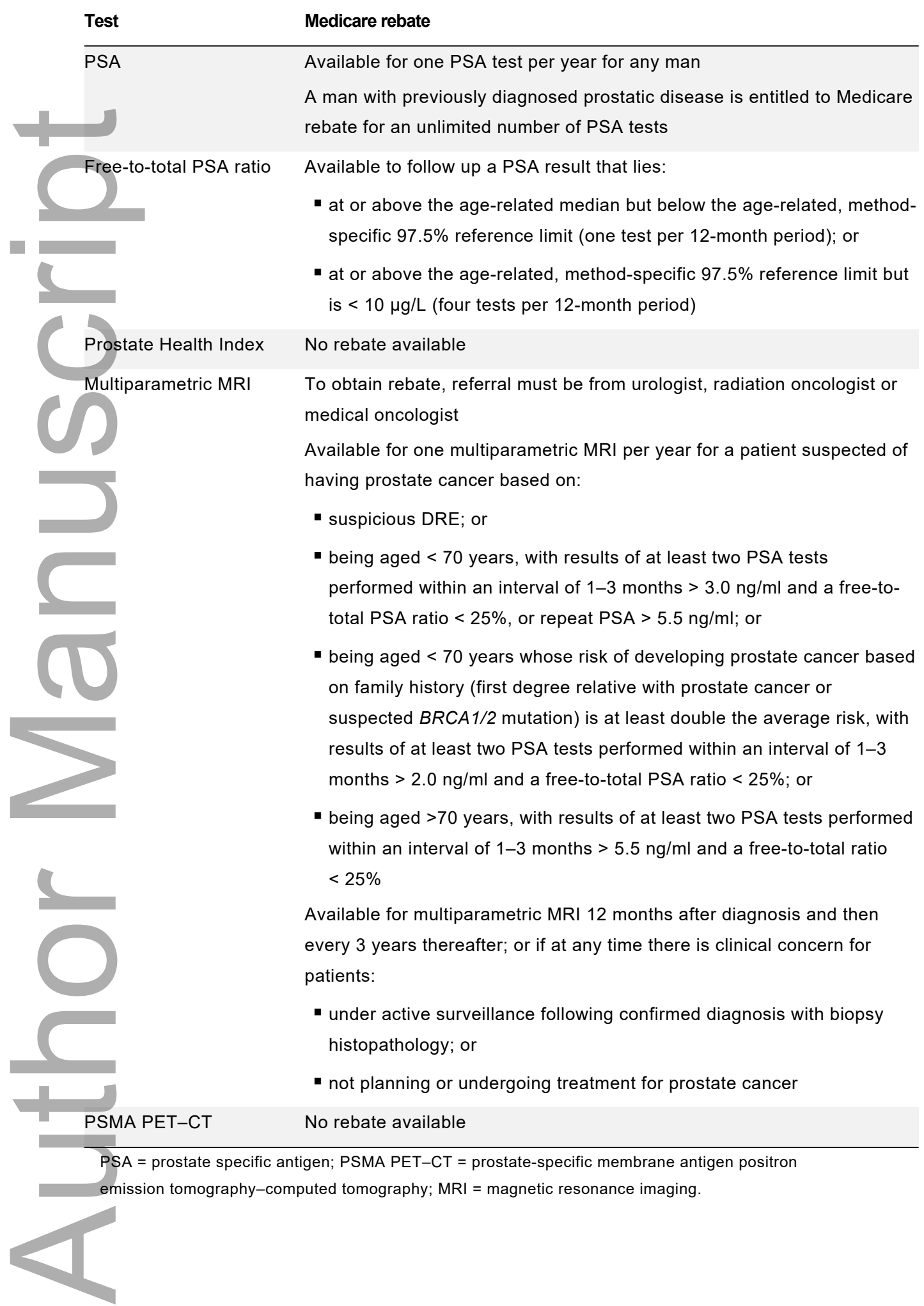


5 International Society of Urological Pathology (ISUP) prostate cancer grades and Gleason score equivalents ${ }^{55}$
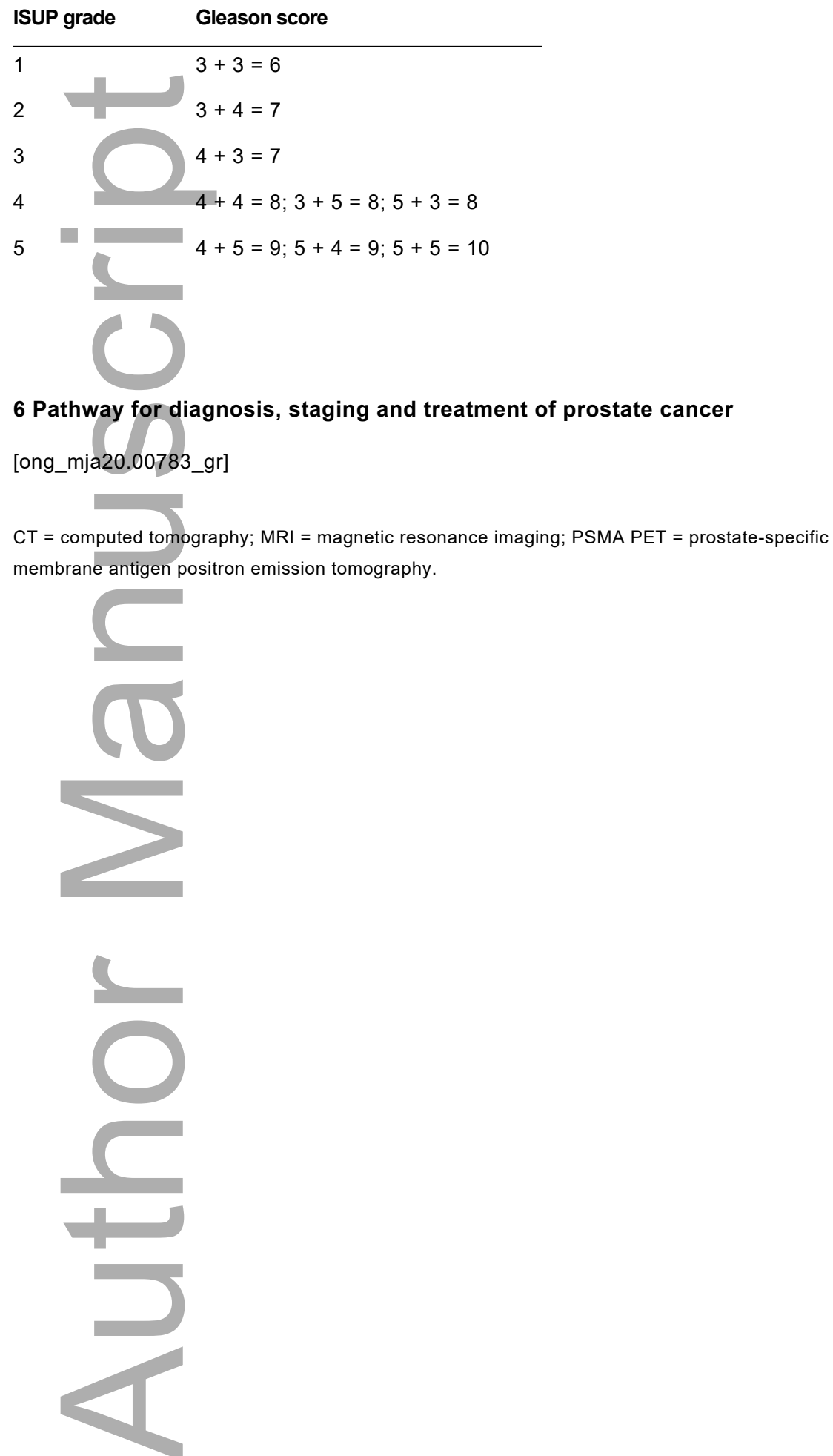

This article is protected by copyright. All rights reserved 


\section{University Library}

\section{- M M N E R VA A gateway to Melbourne's research publications}

Minerva Access is the Institutional Repository of The University of Melbourne

Author/s:

Ong, XRS;Bagguley, D;Yaxley, JW;Azad, AA;Murphy, DG;Lawrentschuk, N

Title:

Understanding the diagnosis of prostate cancer

Date:

2020-10-13

Citation:

Ong, X. R. S., Bagguley, D., Yaxley, J. W., Azad, A. A., Murphy, D. G. \& Lawrentschuk, N. (2020). Understanding the diagnosis of prostate cancer. MEDICAL JOURNAL OF AUSTRALIA, 213 (9), pp.424-429. https://doi.org/10.5694/mja2.50820.

Persistent Link:

http://hdl.handle.net/11343/276441 